\title{
Environmental Literacy: Evaluating Knowledge, Affect, and Behavior of Pre-service Teachers in Greece
}

\author{
Anastasia Goulgouti ${ }^{1}$, Aikaterini Plakitsi ${ }^{1}$, Georgios Stylos ${ }^{2 *}$
}

\begin{abstract}
${ }^{1}$ Department of Pre-school Education, University of Ioannina, GREECE
${ }^{2}$ Department of Primary Education, University of Ioannina, GREECE

*Corresponding Author: gstylos@uoi.gr
\end{abstract}

Citation: Goulgouti, A., Plakitsi, K., \& Stylos, G. (2019). Environmental Literacy: Evaluating Knowledge, Affect, and Behavior of Pre-service Teachers in Greece. Interdisciplinary Journal of Environmental and Science Education, 15(1), e02202. https://doi.org/10.29333/ijese/6287

\section{ARTICLE INFO}

Received: 12 Nov. 2019

Revised: 19 Nov. 2019

Accepted: 19 Nov. 2019

\begin{abstract}
Environmental Literacy can empower individuals to make appropriate environment-related choices and act more responsibly towards the environment. Environmental literacy was measured among a sample of 461 pre-service teachers enrolled at the Department of Pre-school Education at the University of Ioannina, in Greece. Results indicate that pre-service teachers have positive attitudes towards the environment, a moderate level of environmental knowledge while their participation in environmental actions is limited, particularly collective actions. Statistical analyses also highlighted that Environment Literacy depends on year of study and high school course specialization. These findings are further discussed.
\end{abstract}

Keywords: environmental literacy, knowledge, attitudes, behaviour, pre-service teachers

\section{INTRODUCTION}

Environmental protection is a pressing issue in the world as the severity of environmental problems continues to grow (UNESCO, 2016). The majority of environmental problems are due to people's lifestyles and activities (Connell, Fien, Lee, Sykes, \& Yencken, 1999; Onur, Sahin, \& Tekkaya, 2012; Rogers, Jalal, \& Boyd, 2008). Environmental Literacy that can empower people to make thoughtful decisions and act responsibly towards the environment is urgent (UNESCO, 2016). Therefore, Environmental Education has set Environmental Literacy as its goal in order to tackle environmental problems and protect the environment (NAAEE, 2010). In line with this objective, International Conferences, which have taken place over the last decades, highlight the importance for people to change their lifestyle and find ways to prepare young people and involve them in environmental initiatives, that make up Environmental Literacy (NAAEE, 2010; UNESCO, 2005, 2016). Teachers are going to have to undertake the task of developing their students' Environmental Literacy, who will become the world's future citizens and called to make decisions on the environment's protection (Flogaiti \& Liarakou, 2009). The literature review indicates that teachers' Environmental Literacy affects students' Environmental literacy (Goldman, Yavetz, \& Pe'er, 2014). Therefore, the evaluation of in-service teachers' and pre-service teachers' Environmental Literacy is considered important in order to detect any gaps in their environmental knowledge, attitudes and behavior. This paper analyzes future teachers' Environmental literacy and more specifically presents their environmental knowledge, attitudes and behavior towards the environment. Two key questions were addressed:

How do future teachers perform on Environmental Literacy in terms of knowledge, affect, and behavior towards the environment?

What are the correlations between Environmental Literacy (knowledge, affect and behavior) and background factors (gender, year of study and high school course specialization)?

\section{LITERATURE REVIEW}

The environment is a pressing issue in the world as growing consumption leads to environmental problems, therefore many International Conferences highlight the importance of Environmental Literacy (E.L.) in order to address environmental problems and protect the environment (UNESCO, 2016). Specifically, E.L. refers to a person's environmental knowledge and skills, as well as their attitudes, values and behavior towards the environment (NAAEE, 2010). E.L. can empower individuals to make thoughtful decisions and act responsibly which is important in order for people to reconsider their relationship with the environment and change their lifestyle based on the principles of sustainable 
environmental management (Flogaiti \& Liarakou, 2009; Saribas, 2015; Tuncer et al., 2009).

The literature review mentions a variety of factors that appear to affect E.L., the most important of which are environmental knowledge, attitudes towards the environment and responsible environmental behavior (Goldman, et al., 2006, 2014; Liu, Yeh, Liang, Fang, \& Tsai, 2015; Saribas, Teksöz, \& Ertepinar, 2014; Saribas, 2015; Tuncer et al., 2009; Tuncer Teksoz, Boone, Yilmaz Tuzun, \& Oztekin, 2014; Yavetz, Goldman, \& Pe'er, 2009). The research notes that responsible environmental behavior correlates with knowledge and it's likely that people with increased environmental knowledge develop more responsible environmental behavior and more positive attitudes towards the environment (Goldman et al., 2014; Pe'er, Goldman, \& Yavetz, 2007; Tuncer Teksoz et al., 2014; Tuncer et al., 2009; Yavetz et al., 2009). At the same time, attitudes seem to influence responsible environmental behavior (Goldman et al., 2014; Liu et al., 2015; Pe'er et al., 2007; Yavetz et al., 2009). According to surveys, attitudes are mostly influenced by environmental knowledge, environmental actions, family income, and demographic factors such as gender, age and educational level (Boubonari, Markos, \& Kevrekidis 2013; Pe'er et al., 2007; Tuncer Teksoz et al., 2014; Tuncer et al., 2009; Yavetz et al., 2009).

These literature review findings highlight the importance of education and people could become environmentally literate if immersed in a context of Environmental Education with the introduction of Education for Sustainable Development (EE/ESD) into school and university curricula (Plakitsi et al., 2013; UNESCO, 2016). In-service and preservice teachers should understand education for sustainable development as they can develop in their students positive attitudes towards the environment from an early age (Plakitsi et al., 2013; Roth, Goulart, \& Plakitsi, 2011). Research found that students are more likely to be environmentally literate if their teachers have greater environmental knowledge, concerns and positive attitudes and act responsibly towards the environment (Saribas, 2015; Tuncer et al., 2009; Yavetz et al., 2009).

Despite the importance of E.L. international surveys indicate that future teachers have moderate or low environmental literacy, however their attitudes towards the environment are positive (Goldman et al., 2006, 2014; Gwekwerere, 2014; Pe'er et al., 2007; Saribas et al., 2014; Tuncer et al., 2009; Yavetz et al., 2009). Indicatively, in a survey, Saribas et al. (2014) stated that future teachers in primary school have insufficient knowledge on environmental issues, although they have strong positive environmental attitudes and intense concerns. At the same time, Tuncer et al. (2009) highlighted pre-service teachers' low level of knowledge, but positive attitudes towards the environment. More recently, Gavrilakis, Stylos, Kotsis, and Goulgouti (2017) found that primary school pre-service teachers have a moderate level of environmental knowledge however also have positive attitudes towards the environment. Likewise, Maidou, Plakitsi, and Polatoglou (2015) supported that early childhood education pre-service teachers in Greece have a relatively good awareness of environmental issues but score lower on Education for Sustainable Development issues. They are well informed on everyday phenomena related to heat and energy transfer, but they have difficulty understanding how a structure can reduce energy consumption. Similar findings have emerged from other surveys (Boubonari et al., 2013; Goldman et al., 2014; Gwekwerere, 2014; Ikonomidis, Papanastasiou, Melas, \& Avgoloupis, 2012; Liu et al., 2015; Maidou et al., 2015; Pe'er et al., 2007; Saribas et al., 2014; Tuncer Teksoz, 2014; Tuncer et al., 2009).

Simultaneously, research on future teachers' E.L. highlights the misconceptions they continue to have about environmental issues such as the greenhouse effect, acid rain and the ozone hole (Boubonari et al., 2013; Ikonomidis et al., 2012; Maidou et al., 2015; Spiropoulou, Antonakaki, Kontaxaki, \& Bouras, 2007). Indicatively, Boubonari et al. (2013) found that pre-service teachers hold several misconceptions about water pollution. Similarly, Ikonomidis et al. (2012) found that prospective teachers in primary education hold serious misconceptions about environmental concepts mostly regarding the greenhouse effect and ozone layer depletion. In line with the above, the research led by Spiropoulou et al. (2007) found that future teachers hold misconceptions about sustainability and renewable energy, while a more recent survey conducted by Maidou et al. (2015) showed that future pre-school and primary school teachers are adequately informed on issues related to E.L. but less so on those of education for sustainable development as they hold misconceptions on heat transfer.

Therefore, there is a need to evaluate the Environmental Literacy of future teachers in order to make any necessary changes to the curricula across all levels of education.

Therefore, this study examined the E.L. of future teachers enrolled at the Department of Pre-school Education at the University of Ioannina, in Greece. Specifically, it examined the performance of future teachers on environmental literacy in terms of knowledge, affect, and behavior. Correlations between affect, behavior, knowledge and gender, year of study and high school course specialization were also examined.

\section{METHODOLOGY}

\section{Instrument}

For this study a structured questionnaire (Cohen, Manion, \& Morrison, 2007) was selected as the quantitative research method. Specifically, two instruments were used. The questionnaire adopted was a combination of Yavetz, Goldman and Pe'er's questionnaire (2009) and Yencken, Fien, and Sykes' questionnaire (2000). The questionnaire was developed in stages (Beaton, Bundardier, Guillemin, \& Feraz, 2000; Hambleton, 2001). Firstly, it was translated to the Greek language by two different experienced translators and then a third person translated the Greek questionnaire into English. A panel of four environmental science experts evaluated the content validity of the draft questionnaire. The panel included faculty members in science, science education, and environmental science, five in-service teachers and 7 master's level science students. Finally, a pilot study which included 70 fourth-year students and 10 Master of Science students from the Department of Primary Education allowed to create the 
Table 1. Sample's characteristics

\begin{tabular}{ccc}
\hline Gender & $\mathbf{N}$ & Frequency (\%) \\
\hline Men & 32 & 7 \\
\hline Women & 429 & 93 \\
\hline Year of Study & & \\
\hline $1^{\text {st }}$ & 113 & 24 \\
\hline $2^{\text {nd }}$ & 110 & 24 \\
\hline $3^{\text {rd }}$ & 123 & 27 \\
\hline $4^{\text {th }}$ & 115 & 25 \\
\hline High School course specialization & & \\
\hline Sciences & 28 & 6 \\
\hline Technology & 37 & 8 \\
\hline Humanities & 382 & 84 \\
\hline
\end{tabular}

final questionnaire according to the results obtained. The final questionnaire consists of four sections:

(1) demographic and academic characteristics,

(2) 15 statements about environmental behavior from Yavetz et al.'s (2009) questionnaire, and 2 statements from the literature review,

(3) 17 statements about environmental attitudes from Yavetz et al.'s (2009) questionnaire, and

(4) 13 multiple choice questions about environmental and ecological knowledge from Yencken et al.'s (2000) questionnaire.

The questionnaire included a mixture of rank order scaling, multiple choice and Likert type questions.

\section{Research Samples}

The participants in this study were 461 pre-service teachers enrolled at the Department of Pre-school Education at the University of Ioannina, in Greece. The basic demographic and academic characteristics of the students in the sample, i.e. sex, high school course specialization and year of study are presented in Table 1 .

\section{Data Analysis Procedures}

The SPSS 21.0 software package version was used in order to facilitate data analysis. Firstly, the data were converted to numeral scores ranging from 1 to 5 for items in the affect and behavioral domains based on students' responses. Descriptive statistics were calculated for the three domains (cognitive, affect, behavioral). Statistical analyses were performed for gender, high school course specialization and year of study via
Table 3. Total Knowledge scores (\%)

\begin{tabular}{cc}
\hline Number of questions answered correctly & Students (\%) \\
\hline 0 to 3 correct & 36 \\
\hline 4 to 6 correct & 48 \\
\hline 7 to 10 correct & 16 \\
\hline
\end{tabular}

non parametric tests (Mann-Whitney $U$ and Kruskal Wallis Test), since the data were not normally distributed in order to determine if there was a significant difference. The cognitive domain items received a ' 1 ' score if correct and a ' 0 ' score if incorrect and the percentage of correct responses to these items were also computed.

\section{RESULTS AND DISCUSSION}

\section{Overall Survey Results}

A summary of knowledge, affect and behavioral ratings for pre-service teachers is presented in Table 2. The survey results in Table 2 indicate that, overall, the Environmental Literacy level of this sample of pre-service teachers is moderate to low, particularly with respect to their performance on cognitive questions. More specifically, the average percentage of correct answers from pre-service teachers on the knowledge questions was 44.77 . The average level of difficulty on the cognitive questions was close to $50 \%$, which is close to the desired level for a group of questions as a whole.

Affect towards the environment tended to be positive ( $\mathrm{M}=$ $76.34)$ and higher than behavior $(\mathrm{M}=60.83)$. The reliability of the instrument was acceptable ranging from .65 to .80 .

\section{Environmental Knowledge}

Initially, future teachers were asked to answer questions assessing their knowledge about environmental concepts, such as biodiversity, energy, etc. Future teachers' answers show that their level of environmental knowledge is moderate to low, given that out of all questions about half of respondents answered correctly to about half of the questions. The percentage of those who answered correctly to 0 to 3 questions is considered quite high and only $16 \%$ of future teachers answered most of the questions correctly (Table 3). Similarly, Gavrilakis et al. (2017) also discovered that pre-service teachers' environmental knowledge was moderate, with a

Table 2. Overall survey results

\begin{tabular}{lccc}
\hline & Knowledge $^{\mathbf{a}}$ & Affective $^{\mathbf{b}}$ & Behaviour $^{\mathbf{c}}$ \\
\hline $\mathrm{N}$ & 455 & 459 & 459 \\
\hline Mean \pm SD $(\%)$ & $44.77 \pm 22.25$ & $76.34 \pm 8.53$ & $60.83 \pm 10.94$ \\
\hline Mean \pm SD & $4.48 \pm 2.22$ & $57.25 \pm 6.40$ & $45.62 \pm 8.20$ \\
\hline${\text { Responses Mean } \pm \text { SD }^{\mathrm{b}}}^{\mathrm{c}}$ & - & $3.81 \pm 0.42$ & $3.04 \pm 0.54$ \\
\hline Average item difficulty $^{\mathrm{c}}$ & 0.47 & - & - \\
\hline Average discrimination index $^{\mathrm{d}}$ & 0.52 & - & - \\
\hline Reliability $^{\mathrm{e}}$ & .65 & .77 & .80 \\
\hline
\end{tabular}

${ }^{a}$ Knowledge, affect and behavior scores were converted to percent correct.

${ }^{\mathrm{b}}$ Affect and behavior items were measured on a 5-point Likert scale.

${ }^{\mathrm{c}}$ Item difficulty is the percentage of respondents answering each question correctly.

${ }^{d}$ The discrimination index refers to the ability of an item to discriminate between two respondents scoring at two extremes on a particular subscale. General consensus means the minimum discrimination index for a given item should be at least 0.20 (e.g., Benson \& Clark, 1982), and may be as low as 0.15 for educational testing (Hills, 1976).

${ }^{\text {e }}$ Cronbach's alpha $(\alpha)$ internal reliability coefficient 
Table 4. Environmental knowledge scores (\%)

\begin{tabular}{lcc}
\hline Concept & Right & Not sure \\
\hline Biodiversity & 71 & 4 \\
\hline Renewable resources & 60 & 10 \\
\hline Energy & 58 & 6 \\
\hline $\begin{array}{l}\text { Human impact on the carbon cycle (The carbon } \\
\text { cycle) }\end{array}$ & 45 & 35 \\
\hline Sustainable development & 42 & 33 \\
\hline Examples of renewable / non renewable resources & 40 & 36 \\
\hline Ecology & 39 & 8 \\
\hline Importance of tropical rain forests (Biodiversity) & 38 & 27 \\
\hline The greenhouse effect & 31 & 20 \\
\hline The ozone layer & 24 & 29 \\
\hline
\end{tabular}

large percentage of students (47\%) correctly answering 4 to 6 questions. Specifically, the majority of pre-service teachers answered questions about biodiversity (71\%) and renewable energy sources (60\%) correctly, but these percentages were not considered satisfactory (Table 4). Moreover, 1 in 4 pre-service teachers responded correctly to the question related to the ozone hole and about 1 in 3 to that of the greenhouse effect. It is worth mentioning that many future teachers admitted lack of knowledge on many environmental concepts, as 36\% were unsure of which energy sources are renewable and 35\% were confused about the human impact on the carbon cycle. Almost 1 in 3 future teachers are unsure about sustainable development, the ozone hole and the importance of tropical forests. These finding are also consistent with the results of other research studies (Boubonari et al., 2013; Goldman et al., 2014; Gwekwerere, 2014; Ikonomidis et al., 2012; Liu et al., 2015; Pe'er et al., 2007; Saribas et al., 2014; Saribas, 2015; Tuncer Teksoz et al., 2014; Tuncer et al., 2009). More specifically, Pe'er et al. (2007) concluded that students demonstrated an extremely low level of environmental knowledge and Gwekwerere (2014) also showed a moderate level of environmental knowledge in Canadian prospective teachers. Liu et al. (2015) also agree that future teachers have a moderate level of environmental knowledge and Boubonari et al. (2013) demonstrated that pre-service teachers have a relatively moderate level of knowledge concerning marine pollution issues. Similarly, Tuncer Teksoz et al. (2014) found that future teachers have difficulty understanding environmental concepts such as carbon monoxide pollution, hazardous waste and waste management procedures. Consistent with the above findings, Saribas et al. (2014) found that pre-service teachers in Turkey do not have sufficient environmental knowledge especially concerning the issues of nuclear waste and the contribution of motor vehicles to air pollution.

Likewise, answers from future teachers reveal their misconceptions about environmental concepts, despite learning about specific environmental issues during their education and training. Specifically, future teachers' misconceptions concern the ozone hole, energy sources, biodiversity and the concept of ecology. For instance, regarding the greenhouse effect, 1 in 5 pre-service teachers considered that should tropical forests be destroyed, there will be an increase in acid rain (27\%) or in the amount of ultraviolet radiation reaching the Earth (20\%). Similarly, many future teachers believe that ozone depletion is caused by hydrocarbons, carbon dioxide and chlorofluorocarbons (27\%) or by carbon dioxide alone (18\%).

Recent research has also highlighted the misconceptions held by future teachers in relation to specific environmental concepts (Boubonari et al., 2013; Gavrilakis et al., 2017; Gwekwerere, 2014; Ikonomidis et al., 2012; Maidou et al., 2015; Saribas et al., 2014; Spiropoulou et al., 2007; Tuncer Teksoz et al., 2014). For instance, Spiropoulou et al. (2007) showed that in-service teachers held misconceptions about sustainability and renewable and non-renewable energy sources. Similarly, Tuncer Teksoz et al. (2014) found that future teachers had difficulties in identifying sources of carbon monoxide emissions. More recently Gavrilakis et al. (2017) found that pre-service teachers lack knowledge and continue to hold misconceptions about biodiversity, the greenhouse effect, the ozone hole and energy sources while Maidou et al. (2015) found that pre-service teachers hold misconceptions on the topic of heat transfer.

\section{Environmental Attitudes}

Pre-service teacher responses on the affect subscale, while not particularly high, are indeed much better than those on the cognitive subscale (Table 5), indicating that future teachers generally acknowledge the existence of an environmental problem and accept the need to protect the environment. Particularly, pre-service teachers expressed very positive attitudes about the importance of Environmental Education for E.L., as the majority agreed or strongly agreed with the statements. For instance, $92 \%$ of respondents believe that it is every teacher's responsibility to include environmental issues and values in his or her teaching, and $94 \%$ consider it is very important to organize school activities related to the environment, such as excursions, exhibitions, etc.

It is worth mentioning that half of future teachers have no opinion as to whether the law could prevent any environmental damage, even though most of them have positive attitudes towards applying penalties to factories and industries when they damage the environment. At the same time, the majority have a low locus of control, as they do not believe that something can change with their personal actions and behaviors. Finally, it seems that future teachers adopt an anthropocentric system of values for the environment, since $53 \%$ agree that the value of living nature organisms is determined by their usefulness to humans, while $23 \%$ of them have no opinion about the matter.

Moreover, more than half of respondents believe that scientists' concern about environmental problems is excessive, while many (43\%) support that man has the right to exploit natural resources according to his or her needs.

These findings are also consistent with the results of other research studies on positive environmental attitudes (Goldman et al., 2006, 2014, Liu et al., 2015; Pe'er et al., 2007; Saribas et al., 2014; Saribas, 2015; Tuncer et al., 2009; Yavetz et al., 2009). Specifically, Pe'er et al. (2007) which found that pre- service teachers' overall attitudes towards the environment were positive. Liu et al. (2015) found that inservice teachers have satisfactory levels of both environmental knowledge and attitudes. Similarly, Tuncer Teksoz et al. (2014) also discovered that pre-service teachers have positive attitudes. According to Boubonari et al. (2013) Greek future 
Table 5. Pre-service teachers' Responses on Environmental-Related Attitude Items (\%)

\begin{tabular}{|c|c|c|c|c|c|}
\hline $\begin{array}{l}\text { Environmental- related Attitude } \\
\text { items }\end{array}$ & $\begin{array}{l}\text { Strongly } \\
\text { Disagree }\end{array}$ & Disagree & $\begin{array}{l}\text { Have no } \\
\text { opinion }\end{array}$ & Agree & $\begin{array}{c}\text { Strongly } \\
\text { Agree }\end{array}$ \\
\hline $\begin{array}{l}\text { 1. It is every teacher's responsibility to include environmental subjects and values in } \\
\text { his/her teaching. }\end{array}$ & 0 & 1 & 7 & 51 & 41 \\
\hline $\begin{array}{l}\text { 2. Each student in a teacher training institution should be required to study an } \\
\text { environmental course during his/her studies. }\end{array}$ & 0 & 3 & 15 & 50 & 31 \\
\hline $\begin{array}{l}\text { 3. It is very important to organize school activities on the environment - green days, trips } \\
\text { and exhibitions. }\end{array}$ & 0 & 1 & 5 & 39 & 55 \\
\hline 4. It is important to include environmental topics in the educational system. & 0 & 2 & 15 & 42 & 34 \\
\hline 5. Laws reduce damage to the environment. & 3 & 14 & 43 & 31 & 9 \\
\hline 6. Punishment doesn't prevent damage to the environment. & 4 & 16 & 24 & 45 & 11 \\
\hline 7. Factories should be penalized for environmental damage. & 0 & 2 & 12 & 44 & 42 \\
\hline $\begin{array}{l}\text { 8. Industry should be forced to reduce pollutant emissions even if this entails higher } \\
\text { consumer prices. }\end{array}$ & 0 & 5 & 35 & 41 & 19 \\
\hline $\begin{array}{l}\text { 9. I believe I can contribute to the quality of the environment through my personal } \\
\text { behaviour. }\end{array}$ & 1 & 2 & 17 & 58 & 22 \\
\hline 10. There's no use in trying to influence my family or friends on environmental issues.* & 2 & 8 & 16 & 48 & 26 \\
\hline $\begin{array}{l}\text { 11. If I had more knowledge I would integrate environmental considerations into my daily } \\
\text { habits. }\end{array}$ & 1 & 3 & 21 & 62 & 13 \\
\hline 12. It is each person's responsibility to take care of the environment. & 9 & 21 & 19 & 33 & 18 \\
\hline $\begin{array}{l}\text { 13. Even if I save water or energy or purchase environmentally friendly products, it won't } \\
\text { make a difference because the influence caused by other people is too great.* }\end{array}$ & 2 & 21 & 21 & 42 & 14 \\
\hline 14. Concern for the environment is out of proportion.* & 1 & 10 & 28 & 43 & 18 \\
\hline 15. It is humanity's right to exploit nature's resources according to their needs. * & 3 & 19 & 35 & 27 & 16 \\
\hline $\begin{array}{l}\text { 16. Action conducted by single citizens are useless because the ‘authorities' aren’t } \\
\text { impressed by the 'little citizen'. * }\end{array}$ & 3 & 21 & 31 & 36 & 9 \\
\hline 17. The value of living creatures in nature is determined solely by their use for humanity. * & 4 & 15 & 28 & 30 & 23 \\
\hline
\end{tabular}

* negatively-phrased items $(1=5,2=4,3=3,4=2,5=1)$

Table 6. Pre-service teachers Responses on Environmental-Related Behavior Items (\%)

\begin{tabular}{|c|c|c|c|c|c|}
\hline Environmental Actions & Never & $\begin{array}{c}\text { Very } \\
\text { Seldom }\end{array}$ & Sometimes & $\begin{array}{l}\text { Very } \\
\text { often }\end{array}$ & Always \\
\hline $\begin{array}{l}\text { 1. Conserve energy by turning off lights and electric appliances when not in use. (PC, TV, } \\
\text { radio). }\end{array}$ & 2 & 6 & 23 & 48 & 21 \\
\hline 2. Conserve water at home (close faucet when brushing teeth, washing dishes etc.). & 0 & 6 & 19 & 40 & 35 \\
\hline 3. Re-use plastic bags that previously served as shopping bags. & 7 & 13 & 24 & 34 & 22 \\
\hline 4. Re-use used writing paper as draft paper. & 2 & 9 & 21 & 40 & 38 \\
\hline $\begin{array}{l}\text { 5. Purchase ‘environmentally friendly' products (such as: ozone friendly sprays, products } \\
\text { with recyclable packaging, economy size products). }\end{array}$ & 6 & 27 & 38 & 22 & 7 \\
\hline 6. Bring things (such as: newspapers, plastic bottles) to recycling collection points. & 4 & 13 & 28 & 27 & 27 \\
\hline 7.Recycle batteries. & 6 & 14 & 24 & 31 & 25 \\
\hline $\begin{array}{l}\text { 8. Comment to people who throw trash in public space or damage the environment in } \\
\text { any manner. }\end{array}$ & 15 & 26 & 30 & 18 & 11 \\
\hline $\begin{array}{l}\text { 9. Collect things that people have thrown in public areas and dispose of them in trash } \\
\text { barrels. }\end{array}$ & 29 & 31 & 23 & 13 & 4 \\
\hline 10. Participate in campaigns for cleanup and care of public spaces. & 30 & 33 & 25 & 8 & 3 \\
\hline $\begin{array}{l}\text { 11. Report to authorities on environmental problems or send letters to media on } \\
\text { environmental problems. }\end{array}$ & 62 & 21 & 9 & 7 & 1 \\
\hline $\begin{array}{l}\text { 12. Take part in campaigns for prevention of environmental damage (petitions, } \\
\text { demonstrations, etc.). }\end{array}$ & 50 & 28 & 16 & 4 & 2 \\
\hline 13. I'm active in an environmental organization. (Greenpeace, WWF etc.) & 61 & 21 & 10 & 5 & 3 \\
\hline 14. Recycle electric or electronic devices. & 10 & 20 & 24 & 25 & 21 \\
\hline 15. Turn off lights, when leave the room. & 0 & 2 & 5 & 23 & 70 \\
\hline
\end{tabular}

teachers have positive attitudes towards the marine environment and they are also willing to pay additional fees in order to protect the marine environment. Moreover, Saribas et al. (2014) and Tuncer et al. (2009) state that pre-service teachers have positive environmental attitudes. Additionally, Maidou et al. (2015) mention that pre-service teachers in Greece have positive attitudes towards education for sustainable development.

\section{Environmental Behavior}

Although students indicated they were willing to do more, their responses on the behavioral dimension did not generally reflect their positive attitudes (Table 6). Generally, ratings were lower than those for affect, but still positive $(M=60.83$, Table 2). Specifically, almost all future teachers (93\%) reported that they turn off the lights when they leave a room, and $69 \%$ of them shut down electronic devices fairly often or 
Table 7. Analysis of Students' Responses based on Gender

\begin{tabular}{|c|c|c|c|c|}
\hline & Mean & S.D. & Mean rank & Probability* \\
\hline \multicolumn{5}{|l|}{ Knowledge } \\
\hline Male & 4.78 & 2.34 & 244.47 & \multirow{2}{*}{0.46} \\
\hline Female & 4.45 & 2.22 & 226.75 & \\
\hline \multicolumn{5}{|l|}{ Attitudes } \\
\hline Male & 55.83 & 6.94 & 206.40 & \multirow{2}{*}{0.30} \\
\hline Female & 57.36 & 6.36 & 231.71 & \\
\hline \multicolumn{5}{|l|}{ Behavior } \\
\hline Male & 46.22 & 5.78 & 249.64 & \multirow{2}{*}{0.39} \\
\hline Female & 45.57 & 8.36 & 228.53 & \\
\hline
\end{tabular}

* Probability of difference between male and female future teachers' responses was calculated with a Mann-Whitney U test.

Table 8. Analysis of Students' Responses based on High School course specialization

\begin{tabular}{|c|c|c|c|c|}
\hline & Mean & S.D. & Mean rank & Probability $^{a}$ \\
\hline \multicolumn{5}{|l|}{ Knowledge } \\
\hline Sciences- Technology & 5.30 & 2.55 & 260.96 & \multirow{2}{*}{$0.006^{*}$} \\
\hline Humanities & 4.37 & 2.14 & 214.22 & \\
\hline \multicolumn{5}{|l|}{ Attitudes } \\
\hline $\begin{array}{c}\text { Sciences- Technology } \\
\end{array}$ & 58.66 & 6.71 & 254.90 & \multirow{2}{*}{$0.030^{* * *}$} \\
\hline Humanities & 57.04 & 6.36 & 217.54 & \\
\hline \multicolumn{5}{|l|}{ Behavior } \\
\hline $\begin{array}{c}\text { Sciences- Technology } \\
\end{array}$ & 47.00 & 7.04 & 249.05 & \multirow{2}{*}{0.077} \\
\hline Humanities & 45.43 & 8.40 & 21854 & \\
\hline
\end{tabular}

${ }^{a}$ Probability of difference between male and female students responses was calculated with a Mann-Whitney U test.

$* \mathrm{p}<0.01$

***:p $<0.05$

always when they do not use them. Similarly, $75 \%$ of them said they save water at home. In line with the above, 3 out of 4 preservice teachers reuse paper as a draft and more than half reuse plastic and paper bags very often or always. In addition, more than half of future teachers are willing to recycle batteries (56\%), plastic, glass and paper (52\%), but almost $46 \%$ recycle electric and electronic devices.

On the contrary, most future teachers (83\%) stated that they do not submit or very seldomly submit a report to the authorities or mass media about environmental problems. Similarly, $82 \%$ of them don't participate or participate very seldomly in environmental organizations (Greenpeace, WWF, etc.) and around 4 out of 5 don't participate or participate very seldomly in actions (campaigns, demonstrations, protests) aimed at preventing environmental disasters. Similar results have other studies indicating moderate or low levels of participation in environmental actions (Boubonari et al., 2013; Gavrilakis et al., 2017; Goldman et al., 2006; Liu et al., 2015; Pe'er et al., 2007). For example, Gavrilakis et al. (2017) refer to low participation in environmental causes or actions (campaigns, demonstrations, protests). Similarly, Goldman et al. (2006) found limited participation in environmental activism and citizenship actions and Boubonari et al. (2013) state that pre-service teachers scored moderately high on individual action and low on collective action. Similarly, Liu et al. (2015) refer that future teachers presented a low degree of participation in environmental actions despite their positive attitudes towards the environment.

\section{RELATIONSHIP BETWEEN ENVIRONMENTAL KNOWLEDGE, ATTITUDES AND BEHAVIOR AND BACKGROUND FACTORS}

\section{Gender}

Data analysis showed that there was no significant difference based on gender, on pre-service teachers' overall understanding of environmental concepts as well as on the cognitive, affect and behavioral dimensions (Table 7). Similarly, Kroufek, Çelik and Can (2015) found that the gender variable showed no statistical difference except in the subscale consciousness. Similarly, Liu et al. (2015) refer that any differences between gender and the affect or behavior domains were not substantive.

However, surveys indicated that women are more responsible environmentally than men and show greater environmental concern (Goldman et al., 2014; Tuncer Teksoz et al., 2014; Tuncer et al., 2009). For instance, Tuncer Teksoz et al. (2014) found significant differences among men and women on environmental concerns and their attitudes toward the environment, with women showing greater environment concerns and their attitudes being more eco-centric than those of men.

\section{High School Course Specialization}

Table 8 shows that there was a significant difference in all, including the cognitive, affect and behavioral, dimensions of pre-service teachers' understanding of environmental concepts based on High School course specialization. Specifically, students having pursued a Science or Technology 
Table 9. Analysis of Students' Responses based on year of study

\begin{tabular}{cccc}
\hline Year of study & Mean & S.D. & Mean rank $^{\text {Probability }^{\text {a }}}$ \\
\hline 1 st & 16.69 & 2.42 & 213.97 \\
\hline $2^{\text {nd }}$ & 16.52 & 2.46 & 201.91 \\
\hline $3^{\text {rd }}$ & 17.20 & 2.21 & 242.89 \\
\hline $4^{\text {th }}$ & 17.64 & 1.98 & 262.84 \\
\hline
\end{tabular}

*Probability of difference between male and female student responses was calculated with Kruskal Wallis Test, $\mathrm{p}<0.01$

course specialization in High School tended to be more knowledgeable about environmental-related issues than students with a Humanities course specialization. At the same time, students with a science background in High School hold more positive attitudes towards the environment than students with a Humanities background. One interpretation that may explain these findings is that, in Greece, students coming from a science or technology background in high school attended more science courses such as physics and biology. However, students from a Humanities background in high school attended courses such as history and ancient Greek. Similarly, Pe'er et al. (2007), indicate that pre-service teachers who had come from a Science background showed greater knowledge and more positive attitudes towards the environment. Also Kyriazi and Mavrikaki (2015) reached the same conclusions seeing that Science-oriented students scored higher in contrast with the Humanities students.

\section{Year of Study}

The data analysis also shows that there was a significant difference in the affect dimension of pre-service teachers based on year of study. Multiple comparisons conducted among the two show that students in Years 3 and 4 show a more positive attitude than those in the first two years toward the value of Environmental Literacy in the education system. The course curriculum of the department, where the research was conducted, offers several courses on Education for Sustainable Development and the Natural Sciences in the 3rd and 4th year of study. This larger offering of courses could explain these findings, demonstrating how education can help develop Environmental Literacy. Similarly, Kroufek et al. (2015) found that future teachers in their final years of study achieved better results on environmental literacy leading to greater environmentally responsible behavior.

\section{CONCLUSIONS AND POLICY IMPLICATIONS}

\section{Conclusions}

This study aimed at measuring pre-service teachers' Environmental Literacy in light of their performance on cognition, affect and behavior therefore exploring the relationship between these dimensions and background factors, such as gender, High School course specialization and year of study. The results highlighted that future teachers in Greece have positive attitudes towards the environment, a moderate level of environmental knowledge and their participation in environmental actions is limited, particularly with regards to collective actions.
Interesting conclusions regarding pre-service teachers' environmental literacy arise from this research. More specifically, with respect to knowledge this study has shown that future teachers' level of environmental knowledge is moderate as almost half of them answered 4 to 6 questions about environment conceptions correctly. Moreover, this study highlights the misunderstandings held by future teachers regarding certain environmental concepts which they continue to maintain despite learning about these during their studies. This finding leads us to think about environmentrelated concepts included in the school and university curricula, in addition to the way these concepts are taught.

Regarding future teachers' attitudes towards the environment, they do have positive attitudes, particularly regarding the importance of Environmental Education for E.L. They also acknowledge the existence of an environmental problem and accept the need to protect the environment. It is worth noting that future teachers adopt an anthropocentric system of values for the environment.

With respect to the behavioral domain, pre-service teachers' participation in environmental actions is relatively limited and focuses mainly on individual rather than collective actions. Some teaching activities linked to future teachers' life experiences might be helpful, such as encouraging them to observe nature and understand the need for biodiversity, taking part in campaigns on preventing environmental damage or initiatives involving the cleanup and care of public spaces. Additionally, participatory teaching and learning methods such as enquiry-based learning, experiential learning and action competence are considered important in order to motivate and empower learners.

Moreover, in this study, factors such as gender, High School course specialization and year of study and their impact on E.L. were examined. Firstly, regarding the gender factor, the difference between male and female pre-service teachers' overall Environmental Literacy was negligible and not significant. The data analysis did show that E.L. was affected by High School course specialization and year of study. This demonstrates the importance of formal education in building environmental knowledge but also in cultivating attitudes toward the environment and environmentally responsible behavior.

The results of this research emphasize the need for improved environmental education programs in public school, with a broader coverage of topics related to the ways we can protect the environment in everyday life. In addition to learning from the official curriculum, it is important to promote Environmental Literacy through informal school and university curricula and develop decision making skills, value judgment and personal responsibility toward the environment. Education should adopt ways in order to encourage students to 
explore environmental related topics via curricular activities, educational field trips and participation in collective actions for environmental protection. Knowledge, attitudes and behavior towards the environment are not clear enough and they should be investigated further in the future.

\section{Policy Implications}

Finally, this study was an effort to investigate the environmental literacy of future teachers enrolled in the Department of Pre-school Education at the University of Ioannina in Greece. It is important to continue conducting similar surveys periodically in order to assess trends and make informed decisions about how to shape the education curriculum.

\section{REFERENCES}

Beaton, D. E., Bundardier, C., Guillemin, F., \& Feraz, M. B. (2000). Guidelines of the process of cross-cultural adaptation of self-report measures. Spine, 25, 3186-3191. https://doi.org/10.1097/00007632-200012150-00014

Boubonari, T., Markos, A., \& Kevrekidis, T. (2013). Greek preservice teachers' knowledge, attitudes and environmental behavior towards marine pollution. The Journal of Environmental Education, 44, 232-251. https://doi.org/10.1080/00958964.2013.785381

Cohen, L., Manion, L., \& Morrison, K. (2007). Research Methods in Education (6th edn.). London: Routledge. https://doi.org/ 10.4324/9780203029053

Connell, S., Fien, J., Lee, J., Sykes, H., \& Yencken, D. (1999). If doesn't directly affect you, you don't think about it: A qualitative study of young people's environmental attitudes in two Australian cities. Environmental Education Research, 5(1), 95-114. https://doi.org/10.1080/1350462 990050106

Flogaiti, E., \& Liarakou, G. (Eds.). (2009). Ekpaideusi gia tin aeiforo anaptyxi. Apoth theoria sthn praxh, [Education for sustainable development. Absolute theory in practice]. Arhanes: KPE Arhanon.

Gavrilakis, C., Stylos, G., Kotsis, T. K., \& Goulgouti, A. (2017). Environmental literacy assessment of Greek university pre-service teachers. Science Education: Research and Praxis, Special Issue, 61, 49-71. Retrieved from www.lib.uoi.gr/serp

Goldman, D., Yavetz, B., \& Pe'er, S. (2006). Environmental Literacy in Teacher Training in Israel: Environmental Behaviour of New Students. Journal of Environmental Education, 38(1), 3-22. https://doi.org/10.3200/JOEE.38. 1.3-22

Gwekwerere, Y. (2014). Pre-Service Teachers' Knowledge, Participation and Perceptions about Environmental Education in Schools. Australian Journal of Environmental Education, 30(2), 198-214. https://doi.org/10.1017/ aee. 2015.15

Hambleton, R. K. (2001). The next generation of the ITC test translation and adaptation guidelines. European Journal of Psychological Assessment, 17(3), 164-172. https://doi.org/10.1027//1015-5759.17.3.164
Ikonomidis, S., Papanastasiou, D., Melas, D., \& Avgoloupis, S. (2012). The Anthropogenic 'Greenhouse Effect': Greek Prospective Primary Teachers' Ideas about Causes, Consequences and Cures. Journal of Science Education Technology, 21, 768-779. https://doi.org/10.1007/s10956012-9365-0

Kroufek, R., Çelik, C., \& Can, Ş. (2015). The Comparison of Environmental Literacy of Czech and Turkish pre-service primary teachers using Elsa Scale. ResearchGate. Retrieved fromhttps://www.researchgate.net/publication/281711877

Kyriazi, P., \& Mavrikaki, E. (2013). Development of an instrument to measure environmental literacy of postsecondary Greek students - Pilot testing and preliminary results. In C. P. Constantinou, N. Papadouris, A. Hadjigeorgiou (Eds.), E-Book Proceedings of the ESERA 2013 Conference: Science Education Research For Evidence-based Teaching and Coherence in Learning, Part 9 (co-eds. M. Achiam \& G. S. Carvalho), (pp. 1651- 1658). Nicosia, Cyprus: European Science Education Research Association. ISBN: 978-9963-700-77-6

Liu, S., Yeh, S., Liang, S., Fang, W., \& Tsai. H. (2015). A National Investigation of Teachers' Environmental Literacy as a Reference for Promoting Environmental Education in Taiwan. The Journal of Environmental Education, 46(2), 114-132. https://doi.org/10.1080/ 00958964.2014.999742

Maidou, A., Plakitsi, K., \& Polatoglou, H. (2015). Perceptions and attitudes of students towards Education for Sustainable Development. In J. Lavonen, K. Juuti, J. Lampiselkä, A. Uitto \& K. Hahl (Eds.), Science Education Research: Engaging Learners for a Sustainable Future, Part 9 (co-ed.M. Achiam \& G. Carvalho), (pp. 1366-1377). Helsinki, Finland: University of Helsinki.

North American Association for Environmental Education (NAEE) (2010). Guidelines for the preparation and professional development of environmental educators. Washington DC: NAAEE. Retrieved from http://eelinked. naaee.net/n/guidelines/posts/Guidelines-for-the-Preparat ion-amp-Professional-Development-fEnvironmental-Edu cators

Onur, A., Sahin, E., \& Tekkaya, C. (2012). An Investigation on Value Orientations, Attitudes and Concern towards the Environment: The Case of Turkish Elementary School Students. Environmental Education Research, 18(2), 271297. https://doi.org/10.1080/13504622.2011.614690

Pe'er, S., Goldman, D., \& Yavetz, B. (2007). Environmental literacy in teacher training: attitudes, knowledge, and environmental behavior of beginning students. Journal of Environmental Education 39, 45-60. https://doi.org/10.3200/JOEE.39.1.45-59

Plakitsi, K., Spyrtou, A., Klonari, K., Kalogiannaki, M., Malandrakis, G., Papadopoulou, P., Stamoulis, Soulios, J., Piliouras, P., \& Kolios, N. (2011). New Greek Science curriculum (NGSC) for primary education: Promoting educational innovation under hard conditions. In Justin Dillon and Andreas Redfors (Eds.) Science curriculum and educational policy. Proceedings 9th ESERA conference (pp. 1751-1757). Lyon, FR: ESERA. 
Rogers, P., Jalal, K., \& Boyd, J. (2008). An introduction to sustainable development. London: Earthscan.

Roth, W. M., Goulart, M. I., \& Plakitsi, K. (2013). Darkness|Light. In W. -M. Roth, M. I. M. Goulart, K. Plakitsi (Ed.) Science Education during Preschool Years. A CulturalHistorical Approach. Dordrecht, 111-138. The Netherlands: Springer.

Saribas, D. (2015). Investigating the Relationship between PreService Teachers' Scientific Literacy, Environmental Literacy and Life-Long Learning Tendency. Science Education International, 26(1), 80-100.

Saribas, D., Teksöz, G., \& Ertepinar, H. (2014). The relationship between environmental literacy and selfefficacy beliefs toward environmental education. In 5th World Conference on Educational Sciences. Procedia - Social and Behavioral Sciences, (pp. 3664 - 3668). Elsevier Ltd. https://doi.org/10.1016/j.sbspro.2014.01.820

Spiropoulou, D., Antonakaki, T., Kontaxaki, S., \& Bouras, S. (2007). Primary teachers' literacy and attitudes on education for sustainable development. Journal of Science Education and Technology, 16, 443-450. https://doi.org/ 10.1007/s10956-007-9061-7
Tuncer Teksoz, G., Boone, J. W., Yilmaz Tuzun, O., \& Oztekin, C. (2014). An evaluation of the environmental literacy of preservice teachers in Turkey through Rasch analysis. Environmental Education Research, 20(2), 202-227. https://doi.org/10.1080/13504622.2013.768604

Tuncer, G., Tekkaya, C., Sungur, S., Cakiroglu, J., Ertepinar, H., \& Kaplowitz, M. (2009). Assessing pre-service teachers' environmental literacy in Turkey as a mean to develop teacher education programs. International Journal of Educational Development, 29, 426-436. https://doi.org/ 10.1016/j.ijedudev.2008.10.003

UNESCO (2005). United Nations decade for education for sustainable development, 2005-2014: International implementation scheme. Paris, France: UNESCO.

UNESCO (2016). Education for people and planet. Creating sustainable future for all. Final Report. Paris: UNESCO

Yavetz, B., Goldman, D., \& Pe’er, S. (2009). Environmental literacy in pre-service teachers in Israel: A comparison between students at the onset and end of their studies. Environmental Education Research, 15, 393-415. https://doi.org/10.1080/13504620902928422

Yencken, D., Fien, J., \& Sykes, H. (Eds.) (2000). Environment, Education and Society in the Asia-Pacific: Local Traditions and Global Discourses. London: Routledge. 